\title{
VCD And DVD Copyright Protection in Pekanbaru According to Law Number 28 Of 2014 on Copyrights
}

\author{
Moch Roseno Eri*, Syafrinaldi and Admiral \\ PascasarjanaIlmuHukum, Universitas Islam Riau,113, Jalan. KaharuddinNasution, Pekanbaru, Riau-28284, \\ Indonesia \\ *Corresponding author email: syarinaldi@law.uir.ac.id
}

\begin{abstract}
Copyright infringement in a form of VCD and DVD piracy is a despicable and disgraceful act. Piracy is carried out with an intent to earn maximum benefit using someone else's creativity, innovation, and creation. Copyright protection is stipulated under the Law Number 29 of 2014 on Copyright. Each creativity, innovation as well as creation made, invented with ideas have legal protections that allows maximum protection towards the holder of such rights. However, there are numbers of practices carried out by the community to illegally copy a copyrighted works, in which those piracies contribute to losses towards the holder, both morally as well as monetary. Therefore, these practices are contrary to legal protection of copyright nor does it respect the rule of law that this country holds and believes.
\end{abstract}

Keywords: VCD, DVD, According, Copyrights

\section{INTRODUCTION}

Humans are social beings who are endowed the ability to think and act to create, innovate and discover something, which are useful both towards their personal lives and the society. For the said works, the copyright holder is expecting legal protection for his creation[1] to ensure legal certainty for the creations.

Copyright is an exclusive right that allows the holder of the right to distribute and/or copy the works and/or the right of licensing, which does not reduce the restrictions according to the prevailing laws and regulations. Copyrights are the result of each creator's works, showing authenticity in the scientific field[2], art or literature. Legal issues concerning Intellectual Property Right is indeed very important considering the fact that the protection for such rights are not solely the responsibility of the government, each and everyone of us holds the responsibility[3]. IPR is not merely a matter of name and dignity, IPR is a means to earn monetary benefits towards the creator's livelihoods[4].

IPR first emerged in Venetia, Italy in 1470 and related to patent which was then adopted by the United Kingdom in the 1500s and during those years, many other countries were also adopting the IPR, harmonization was carried out in 1883 resulting in Paris Convention concerning patent, trademarks and industrial design. Indonesia is among the countries that is adopting the Paris convention where
Indonesia covers the IPR protection under Law Number 28 of 2014 on IPR. IPR is considered property due to the fact that the Intellectual Poperty is resulting in creations of the mind such us knowledge, art, literature, and technology that required energy[5], money, time and thoughts in its realization. Therefore, Intellectual Property becomes a valuable property which holds an economic benefit[6] in which those benefits is directly enjoyed by the holder. Therefore, these inherent economic value of the said creations fosters the concept of property towards an intellectual work[7].

One form of copyright that was later poured into VCDs and/or DVDs was the sound recording (music) and film producers. For the copyright holders, each of the sound recording (music) or film that has been produced that is then inserted into a VCD and/or DVD holds an economic value through every copy and purchase of that VCD and/or DVD, the copyright holder earns its economic value, namely the royalty from the sale. Moreover, tax is also paid to the state through each purchases of the VCD and/or DVD. Therefore, whoever buys each piece of VCD and/or DVD legally contributes a certain amount of royalties to the copyright holder, and at the same time pays taxes to the state. In case an individual buys a pirated VCD and/or DVD what they are buying is the disc, not the contents of the VCD or the DVD. 
The massive case of violation of Copyright is a cause for concern due to the fact that the losses incurred for these violations are very detrimental to the copyright holder, both in terms of morally and materially. Violations committed through various media, one of which is by downloading a song or video on YouTube, and then transferring it to a VCD or DVD, which then is packaged properly, copying the original form, including song piracy both from the national music industry and international music industry. Until now, song piracy have become increasingly common and are very difficult to overcome.

Copyright infringement in Pekanbaru was driven by one's inability to purchase from the original work due to economy, this condition is escalated by public's ignorance regarding the IPR infringement. Some irresponsible parties see this as an opportunity to intentionally and knowingly commit an infringement by illegally copying a protected copyright and distribute these copyrighted works in a much lower price. This condition is inseparable from the role of the society as the consumers where there is an absence of guilt. People blatantly purchase from pirated copyrighted works and there is a sense of pleasure by purchasing the pirated works because these pirated works are much cheaper than the original works but they can still enjoy the content of the original works. This certainly does not reflect the values of Pancasila, and more especially Law Number 28 of 2014 on Copyright.

That being the case, Author is keen to do a research on this matter titled "VCD and DVD Copyright Protection in Pekanbaru According to Law Number 28 Of 2014 On Copyrights".

\section{RESEARCH METHOD}

This research is en empirical research drawn from concretely empirical evidence by directly observing the field. This legal research has the means for observing the correlation between law and society in order to identify the effectiveness of law enforcement in society. The data used in conducting this research is the primary data obtained directly, by visiting the respondent for the accuracy of the required data, which is directly related to Legal Protection of Copyright. This research is a descriptive research and aims to determine a certain matter with a high degree of accuracy, narrating the characteristics, conditions and symptoms of an individual or to determine the spread of a symptom, or to determine whether or not there is a relationship between a symptom and other symptoms in society[8].

\section{RESULT AND DISCUSSION}

According to Article 1 paragraph (3) of the 1945 Constitution of the Republic of Indonesia which states that "The State of Indonesia shall be a state based on the rule of law[9]", meaning that everything related to social life, nation and state, are regulated by law. To regulate all human interests, rights and responsibilities in action, a law is created which aims to regulate mankind, be it the interests of individuals, groups, society or an institution[10].

One way the law regulate communities' lives is the issuance of Law Number 28 of 2014 on Copyright. Modernity has lead to a life where we depended on copyrights from music, watching movies and video gaming as well as online gaming. These are all products of intellectual property. All forms of copyright is protected and guaranteed by the laws. Copyright that are protected by the laws are as follows:

\section{Law Number 28 of 2014}

Article 40

1) Protected Works which include scientific, artistic, and literary Works, comprise:

a. Books, pamphlets, typholographical arrangement of published written work, and all other written works;

b. Talks, lectures, speeches, and other similar Works;

c. Visual aids made for educational and scientific purposes;

d. Songs and/or music with or without lyrics;

e. Dramatic works, musical dramas, dances, choreography, puppet shows, pantomimes;

f. Fine art works in any forms such as paintings, drawings, engravings, calligraphy, carvings, sculptures, or collage;

g. Applied art works;

h. Architectural works;

i. Maps;

j. Batik art works or other patterns art;

k. Photographic works;

1. Portraits;

m. Cinematographic works;

n. Translations, interpretations, alterations, anthologies, databases, adaptation, arrangement, modification and other works resulting from transformation;

o. Translation, adaptation, arrangement, transformation, or modification of traditional cultural expressions;

p. Compilation of Works or data, whether in a readable format by Computer Program or by other media;

q. Compilation of traditional cultural expressions as long as the compilation constitutes an original work; 
r. Video games; and

s. Computer Programs.

2) The Works as referred to in section (1) point $n$ are protected as Works in their own right without prejudicing the Copyright on the original Works.

3) The protection as referred to in section (1) and section (2) includes the protection for Works that have not been Published but have already embodied in tangible form allowing the Reproduction of such Work.

Music is one of the protected creations as it is included under the field of art, where lots of energy, money, thoughts and time are required in the making of it. Therefore, when the song has been completed, the song is included as one of the works that are protected in accordance to the Law Number 28 of 2014. Even then, there are still numbers of cases of copyrighted works carried out by irresponsible parties.

Secretary general of Asirevi (Indonesian Video Recording Industry Association) asserts that the rampant piracy of copyrighted works has had a terrible and detrimental impact on copyright holders and the state. As he claimed, many consumers purchase pirated VCD/DVD discs under the pretext of practicality, low prices, and easy access, in addition to the ease of using pirated VCD/DVDs, compared to purchasing from original VCD/DVD. This is also exacerbated by the free circulation of pirated VCD/DVD in Pekanbaru[11].

Technological developments contribute to facilitating copyright infringement. In the past 10 years, people have not really understood the use of the internet, listening to music through YouTube whereas the cost of using internet was still quite expensive back then. Nowadays driven by globalization, all activities have gone through the means of internet technology. Learning through the internet, watching and listening to music is also made easy by using the internet, moreover, the internet is not as expensive as it used to be. Irresponsible parties see this as an opportunity. Committing copyrighted works by downloading a video or music on YouTube, then inserting it into a VCD/DVD and distributing it to the public. Needless to say, as a result of the ease of access, the benefits of this violation are very promising.

Based on field observations, the Head of Criminal Investigation Unit of Pekanbaru Police declared that violation of Intellectual Property Rights is an act that is not praiseworthy and despicable as this actions causes losses towards the copyright holders as they do not earn economic benefits at all due to these activities. The state experiences losses on it as well considering that every purchase of VCD/DVD chips, the state receives income from taxes. Meanwhile, illegal tapes give absolutely no benefit to the state and copyright holders. The piracy activities carried out are included under the elements of crime, which harm other people, institutions or the state[12].

As a law enforcer, the Pekanbaru Police have provided education and strict sanctions to traders who sell pirated VCDs/DVDs, so as not to make the identical mistakes repeatedly. However, thus far, piracy of copyright works is still rampant, which is carried out so blatantly, therefore law enforcement officials impose severe sanctions on traders, by withdrawing the circulation of the illegal VCD/DVD from circulation.

One of the respondents from the illegal $\mathrm{VCD} / \mathrm{DVD}$ traders group stated that, it is very rare for the legal authorities to take firm action and impose sanctions on traders of illegal VCD/DVD as there are no parties reporting regarding the losses they have suffered from their activities, this leads to the irresponsible parties to commit the acts blatantly with such ease. This is demonstrated by the increasing number of traders selling pirated VCD/DVDs to this day. The traders also do not realize that the existing sanctions to ensnare them are very strict, emphasized under Law Number 28 of 2014 on Copyright, namely:

Article 113 Paragraph (4)

Every Person fulfilling the elements as referred to in section (3) by committing piracy, shall be sentenced to imprisonment for up to 10 (ten) years and/or fine up to Rp4,000,000,000.00 (four billion rupiahs).

\section{Article 114}

Every Person managing business premises in all its forms who deliberately and knowingly allows the sale and/or duplication of goods resulting from infringement of Copyright and/or Related Rights in the premises that they manage as referred to in Article 10 shall be sentenced with a maximum fine of Rp100,000,000.00 (one hundred million rupiahs).

Despite the fact that copyright infringement towards an individual or groups are considered a criminal act with consequences such as imprisonment and fine, illegal traders are yet committing these practices for the reason that these practices offer lots of benefits for the traders. Furthermore, there is an absence of deterrent effect as the traders never witness other illegal traders being charged for their acts. This of course drives more irresponsible parties to commit such crimes as there seems to be little to no consequences for the act.

Traders of the illegal works are fully aware that the works they pirated hold economic benefits[13] towards the copyright holder. Those said benefits are stipulated under the laws, which are: 
Article 8

Economic rights are the exclusive right of the Author or the Copyright Holder in order to gain economic benefits from the Works.

\section{Article 9}

1) The Author or the Copyright Holder as referred to in Article 8 has the economic rights to engage in:

a. Publication of the Works;

b. Reproduction of the Works in all its forms;

c. Translation of the Works;

d. Adaptation, arrangement, or transformation of the Works;

e. Distribution of the Works or their copies;

f. Performance of the Works;

g. Publication of the Works;

h. Communication of the Works; and

i. Rental of the Works.

2) Every Person who exercises the economic rights as referred to in section (1) is obligated to obtain permission from the Author or the Copyright Holder.

3) Every person is prohibited from exercising Reproduction and/or Commercial Use without any permission from the Author or the Copyright Holder. What the traders are committing is clearly violating the law. Without permit and/or license from the copyright holders, these traders illegally copy and commercially distributing these works to the public. These traders are fully aware that duplicating and pirating are illegal, but nevertheless, poverty drives them to do so[14].

Due to the behavior of traders that often commit copyright infringement, Indonesia has been criticized by the international community for its weak legal protection against copyright, according to a report by the United States Trade Representative's office of the United States of America, before 2000, Indonesia was the only one ASEAN countries that are included in the Priority Watch List category (under this list, the violation of Intellectual Property Rights is classified as severe so that the United States feels the need to prioritize its supervision of Intellectual Property Rights violations in a trading partner country)[15].

In some cases of Copyright infringement, legal protection of Copyright is usually carried out by Copyright Holders through civil law[16]. Regulations on copyright, patent, trademarks, and other intellectual property rights falls under civil law specifically concerning property. Property right consisted of material right and immaterial right. This article focuses on material property known as Intellectual Property Rights consisting of copyright and industrial property rights[17].

According to Satjipto, legal protection provides protection for human rights that are violated by other party, and the protection itself is also given to the community so that they can enjoy the rights provided by law[18]. Therefore, each and every person should not violate the rights that have been attached to a person, group or institution, let alone the piracy of songs carried out by traders which is clear evidence that pirates and traders have collaborated to take the rights attached to the Creator or Copyright Holder.

Nevertheless, piracy[19] and Copyright infringement still occurs, and is commercialized freely and illegally. Even the secretary general of ASIREVI stated that most of the traders selling pirated VCDs / DVDs did not only pirate songs (music) from domestic industries, but also from foreign music industries. Even the number of VCD/DVD pieces that were pirated reached hundreds of thousands of pieces. It can even be said that Indonesia is a "piracy paradise" of intellectual property rights, and even the state is disadvantaged by this in billions[20].

Indonesia is fully committed to protect these IPRs, therefore, Indonesia continually established product of law that is useful in protecting the IPR from infringement carried out by the irresponsible parties. These product of laws began with Law Number 6 of 1982 on Copyright followed by Law Number 7 of 1987 which then amended by Law Number 12 of 1997, which then renewed by Law Number 19 of 2002 with the most recent amendments through Law Number 28 of 2014 on Copyright.

The numbers of amendments to the Law on Copyright was necessary to adjust to the needs and shows the seriousness of the Indonesian people to eradicate Copyright infringement by irresponsible individuals. Even then, there are still individuals who dared enough to take the risk of committing copyright infringements due to the fact that the benefits obtained from the results of these violations are able to support their daily needs.

The result of these actions lead to labels directed towards Indonesia as the land of copyright violations. According to the Head of Pekanbaru District Attorney, duplication/piracy is considered a crime because of the serious impact it holds towards the copyright holders and the benefits enjoyed by the criminals. This has seriously damaged the image of Indonesia as a law state[21].

From the perspective of penal law[22], practices of copyright infringement falls under ordinary offense, not by accusation. Which means that legal enforcement officers are obliged to take immediate action towards copyright violations without expecting the holder to file a complaint against his works that are pirated.

Pirated VCD/DVD traders additionally admit that during their trading activities of pirated VCD/DVDs, they have never been arrested by the police for these activities. This is a cause for concern 
as the lack of enforcement cause these illegal trading to spread freely, some traders are even caught opening a new store branch in another region to sell these pirated works.

For the enforcement to take place, police and other related parties must synchronize and integrate, from the police investigators to civil servant investigators as these activities are considered criminal acts that must immediately be rid of in order to provide legal protection to Copyright holders that can ensure the legal certainty towards the holders. The imposition of ordinary offenses in Copyright issues is deemed inaccurate considering that these matters affect the holders directly, meaning that he and only he knows when his works are being pirated.

This is the result of the absence of guilt in the society for their actions that indirectly supports the widespread of the illegal pirated works. It is also undeniable that there is still a mishap regarding Intellectual Property Rights between law enforcers and the public, which results in rampant traders selling pirated VCDs/DVDs.

Handful of people considers trading of pirated works to be a minor violation and there are huge numbers of constant offender and regular customers of these pirated works. For that reason, there was a neglect and in a short time the crowd followed while not being convicted. This is the mentality of so many people, specifically in Pekanbaru.

Countermeasure shall not merely depend on law enforcement officers, society's awareness regarding the issue of the copyright infringement is equally as important. In order to create social control between fellow citizens who are aware of the law and there so the practices of Copyright infringement will automatically be reduced

Indonesia has facilitated adequate protection for copyright through Law Number 28 of 2014 on Copyright which regulates all forms of Intellectual Property in the fields of science, art and literature which have a strategic role in building the nation. However, inadequate implementation has resulted in some individuals, groups and institutions being disadvantaged, but on the other hand poor implementation resulted in individuals taking advantage of the situation by seeking economic benefits.

\section{CONCLUSION}

The occurrence of massive piracy carried out by certain individuals in order to earn economic benefits is inseparable from the lack of supervision and action by law enforcement officials and those involved in protecting Copyright. These acts are then indirectly supported by the public who enjoyed these pirated VCDs/DVDs. In addition to the low price, the quality of the pirated VCD/DVD that is presented is pretty much the same to the original
VCD / DVD, what distinguishes it is the absence of royalty and tax payments. Under piracy or illegal copying, the access is very wide open, internet is the only medium needed by the irresponsible people to be able to download all the songs or videos that they will duplicate without bothering to copy these materials from the original VCD/DVD. As a result, copyright infringement still occurs, not only due to weak supervision and enforcement and the ignorance of some people, but the ease of accessing a copyrighted work is also used by a handful of irresponsible individuals.

The societies are expected to appreciate a creative work that holds a very high value of knowledge, art and literature, and prefers to use original VCD/DVD rather than pirated ones, apart from this being illegal, choosing original VCD/DVD compared to pirated ones shows our contribution to Copyright Holder and the State. Especially to the Indonesian Police as law enforcers to directly take action against people who have actually vilated or are still indicated to have violated the Copyright of pirated VCDs/DVDs that are still circulating very freely in Pekanbaru, thus providing a deterrent effect and an example to the public that it is not justified to duplicate, pirate and commercialized these illegal works for economic gain.

\section{REFERENCES}

[1] Much. Nurrachmad, Segala Tentang HAKI Indonesia, Buku Biru, Yogyakarta, 2012, P. 18. 2012.

[2] Kholis Roisah, "Kebijakan Hukum 'Tranferbility' Terhadap Perlindungan Hak Kekayaan Intelektual Di Indonesia," J. Law Reform, Semarang, vol. 11, No 2, 2015.

[3] Syafrinaldi, Hukum Tentang Perlindungan Hak Milik Intelektual: Dalam Menghadapi Era Globalisasi, UIR Press, Pekanbaru, 2000, P. 1. 2000.

[4] Syafrinaldi., Hak Milik Intelektual dan Globalisasi: Cetakan Kedua, UIR Press, Pekanbaru, 2006, P. 1. 2006.

[5] Afrillyanna Purba, Gazalba Saleh, Andriana Krisnawati, TRIPs-WTO \& Hukum HKI Indonesia (Indonesian Traditional Batik Art Copyright Protection Study), PT. Rineka Cipta, Jakarta, 2005, P. 3. 2005.

[6] A. P. Pebri Tuwanto, Kholis Roisah, "Perlindungan Hak Kekayaan Intelektual (HKI) Terhadap Invensi Di Luar Angkasa," Diponegoro Law Journal, vol. 5 No 3, P., 2016.

[7] Budi Agus Riswandi, M. Syamsudin, Hak Kekayaan Intelektual dan Budaya Hukum, PT. Raja Grafindo, Jakarta, 2004, P. 31. 2004. 
[8] Amiruddin, Zainal Asikin, Pengantar Metode Penelitian Hukum, PT Raja Grafindo Persada, Jakarta, 2010, P. 25. 2010.

[9] Undang-Undang Dasar Negara Republik Indonesia, Tahun 1945, Pasal 1 ayat (3). 1945.

[10] Pipin Syarifin, Pengantar Ilmu Hukum, CV. Pustaka Setia, Bandung, 1999, P. 12. 1999. 